\title{
PENERAPAN MODEL PEMBELAJARAN KOOPERATIF TIPE STUDENT TEAMS ACHIEVEMENT DIVISION (STAD) BERBANTUAN MEDIA PUZZLE UNTUK MENINGKATKAN HASIL BELAJAR PADA MATA PELAJARAN IPA
}

\author{
Wiriya Suwandi ${ }^{1}$, Dewa Nyoman Sudana ${ }^{2}$ \\ Jurusan TP, FIP \\ Universitas Pendidikan Ganesha \\ Singaraja, Indonesia \\ e-mail: wirya3011@gmail.com, dewanyomansudana@undiksha.ac.id
}

\begin{abstract}
Abstrak
Tujuan penelitian ini adalah untuk meningkatkan hasil belajar IPA dengan menggunakan model pembelajaran Kooperative Student Teams Achievement Division (STAD) Berbantuan Media Puzzle pada siswa kelas V semester II di SD N 4 Kaliuntu tahun pelajaran 2017/2018. Desain penelitian ini adalah penelitian tindakan kelas dua siklus. Subjek penelitian adalah siswa kelas V SD N 4 Kaliuntu Semester II Tahun Ajaran 2017/2018. Data penelitian hasil belajar IPA siswa dikumpulkan dengan metode tes dan alat pengumpul data adalah tes hasil belajar dan lembar obeservasi (aktivitas guru dan siswa). Data dianalisis dengan menggunakan teknik analisis statistik deskriptif Dengan menerapkan model Cooperative Learning tipe STAD dapat meningkatkan hasil belajar IPA siswa kelas V di SDN 4 Kaliuntu. Hal ini terlihat dari adanya peningkatan hasil belajar pada siklus I ke siklus II, yaitu pada siklus I, nilai rata-rata kelas adalah 72,63 yang berada pada kategori cukup baik, dengan persentase ketuntasan belajar $60,52 \%$, sedangkan pada siklus II, nilai rata-rata kelas adalah 80,65 yang berada pada kategori baik, dengan persentase ketuntasan belajar $89,47 \%$. Perubahan ini terjadi karena penerapan model Cooperative Learning tipe STAD dilaksanakan secara seksama dengan memperhatikan karakteristik dan kesulitan siswa.
\end{abstract}

Kata-kata kunci: Model pembelajaran Cooperative Learning tipe STAD

\begin{abstract}
The purpose of this study is to improve the learning outcomes of IPA by using the learning model of Cooperative Teacher Achievement Division (STAD) Assisted Media Puzzle on Grade $V$ students in second semester at SD N 4 Kaliuntu in the 2017/2018 school year. The design of this research is a second class action research cycle. The subjects of the study were the students of grade V SD N 4 Kaliuntu Semester II of the academic year 2017/2018. Research data of students' IPA learning outcomes collected by test methods and data collection tools are test of learning result and obeservation sheet (teacher and student activity). Data were analyzed by using descriptive statistic analysis. By applying STAD model Cooperative Learning model can improve the learning result of science student of class V in SDN 4 Kaliuntu. This can be seen from the increase of learning outcomes in cycle I to cycle II, that is in cycle I, the average value of the class is 72.63 which is in good enough category, with the percentage of learning mastery $60,52 \%$, while in cycle II, the average grade is 80.65 in the good category, with the percentage of learning mastery $89.47 \%$. This change occurs because the application of STAD type Cooperative Learning model is carried out thoroughly by taking into account the characteristics and difficulties of students.
\end{abstract}

Keywords: STAD type Cooperative Learning learning model 


\section{Pendahuluan}

Pendidikan adalah investasi jangka panjang yang memerlukan usaha dan dana cukup besar. Bangsa indonesia perlahan-perlahan mulai menyadari pentingnya investasi masa depan terutama pada bidang pendidikan, tidak hanya terfokus pada bangunan fisik semata, pemebenahan dalam bidang pendidikan mulai dilakukan secara menyeluruh yang meliputi aspek moral, ahlak, budi pekerti, perilaku, pengetahuan, kesehatan, keterampilan dan seni yang dikembangkan melalui pembelajaran dan pelatihan, maka pemerintah telah mengadakan perbaikan sistem pendidikan nasional dengan menyempurnakan kurikulum

Hal ini sesuai dengan tujuan pendidikan nasional yang tercantum dalam undangundang sistem pendidikan nasional no. 20 tahun 2003 bahwa "pendidikan adalah usaha sadar dalam rangka menyiapkan peserta didik untuk meningkatkan mutu disemua jenjang pendidikan", mulai dari pendidikan dasar sampai pendidikan tinggi mulai kegiatan pembimbingan dan pengajaran untuk masa yang akan datang.

Dengan penegasan diatas berarati peningkatan kualitas sumber daya manusia haruslah dilakukan dalam konteks pengetahuan dan keterampilan mulai dari hal yang kecil, diantara meningkatkan hasil belajar melalui model dan media pengajaran yang efektif dan efesien serta mengikuti perkembangan zaman.

Kemajuan dibidang ilmu pengetahuan dan teknologi memberikan dampak yang signifikan terhadap sistem pengajaran. Pandangan mengenai konsep pengajaran terus menerus mengalami perkembangan sesuai dengan kemajuan ilmu pengetahuan dan teknologi.

Sejauh ini pendidikan masih didominasi oleh pandangan pengetahuan sebagai perangkat fakta-fakta yang harus dihapal. Kelas masih berpusat pada guru sebagai sumber utama pengetahuan, kemudian ceramah menjadi pilihan utama strategi belajar. Untuk itu diperlukan sebuah strategi baru yang lebih mengaktifkan siswa. sebauh strategi yang tidak mengharuskan siswa menghafal fakta-fakta, tetapi sebuah strategi yang mendorong siswa mengkonstruksi pengetahuan yang ada dalam diri mereka.

Ada kecenderungan dewasa ini untuk kembali pada pemikiran bahwa, anak akan belajar lebih bermakna jika anak mengalami apa yang dipelajarinya atau pembelajaran yang kontekstual. Pembelajaran yang berorientasi target penguasaan materi terbukti berhasildalam kompetensi jangka pendek, tetapi gagal dalam membekali anak untuk memecahkan masalah dalam jangka panjang.

Berdasarkan hasil observasi pendahuluan di kelas V SD Negeri 4 Kaliuntu berupa pengamatan ketika pelaksanaan pembelajaran serta wawancara dengan guru kelas $V$ pada hari selasa, tanggal 6 februari 2018pukul 07.42-09.10 Wita, peneliti menemukan beberapa permasalahan yaitu dapat dilihat bahwa hasil belajar IPA untuk KD 3.1 terkait dengan materi siklus air yang diperoleh siswa kelas V SD Negeri 4 Kaliuntu pada semester ganjil tahun 2017 masih terbilang rendah. seharusnya siswa mencapai nilai 70 sesuai dengan Kriteria Ketuntasan Minimal (KKM) yang telah ditetapkan. Tetapi berdasarkan data yang diperoleh, hanya 25 orang siswa $(65 \%)$ dari 38 orang siswa yang mencapai Kriteria Ketuntasan Minimal (KKM), sedangkan 13 
orang siswa (35\%) belum mencapai Kriteria Ketuntasan Minimal (KKM) yang telah ditetapkan tersebut.

Hal ini disebabkan oleh beberapa faktor yang diantaranya kondisi kelas yang kurang kondusif, guru tidak menggunakan model pembelajaran yang inovatif dan kooperatif, sehingga siswa cenderung bosan dengan kondisi tersebut. Tentu ini sangat berpengaruh tehadap hasil belajar siswa.

Berdasarkan hasil penelitian yang dilakukan oleh Slavin (Rusman 2012:205-206) dinyatakan bahwa:(1) penggunaan pembelajaran kooperatif dapat meningkatkan prestasi belajar siswa dan sekaligus dapat meningkatkan hubungan sosial, menumbuhkan sikap toleransi, dan menghargai pendapat orang lain, (2) pembelajaran kooperatif dapat memenuhi kebutuhan siswa dalam berpikir kritis, memecahkan masalah, dan mengintegrasikan pengetahuan dengan pengalaman. Disamping itu menurut hasil wawancara dengan salah satu siswa kelas V SDN 4 Kaliuntu pembelajaran IPA dianggap sangat membosankan karena pembelajaran IPA hanya mengandalkan komunikasi satu arah, guru dianggap satu-satunya sumber belajar. Metode pengajaran yang masih bersifat konvensional, dimana guruhanya mengandal buku guru sebagai acuan dalam mengajar dan siswa mengerjakan latihan dari buku siswatanpa sebuahmedia yang dapat membantu pemahaman mereka.

Menurut Susiliana dan Riyana (2009:25) "media merupakan salah satu faktor penentu keberhasilan pembelajaran. Melalui media, proses pembelajaran bisa lebih menarik dan menyenangkan". Oleh sebab itu, guru perlu menggunakan media dalam proses pembelajaran, karena menurut Daryanto (2011:6) proses "pembelajaran merupakan proses komunikasi dan berlangsung dalam satu sistem maka media pembelajaran menempati posisi yang cukup penting sebagai salah satu komponen sistem pembelajaran sebagai proses komunikasi juga tidak akan bisa berlangsung secara optimal".

Berangkat dari pendapat di atas, pembelajaran dengan menggunakan model pembelajaran kooperatif dan media sangat tepat untuk mempermudah siswa untuk memahami materinya. Disisi lain suasana belajar akan lebih hidup, dan komunikasi antara guru siswa dapat terjalin dengan baik, hal ini dapat membantu siswa dalam upaya meningkatkan hasil belajar IPA siswa dan model pembelajaran kooperatif yang digunakan adalah Student Teams Achievement Division (STAD) dan salah satu media yang dapat digunakan dalam modelpembelajaran kooperatif pada mata pelajaran IPA adalah permainan puzzle. jenis permainan ini sangat sesuai dengan karakteristik anak SD yang umurnya berkisar $6-12$ tahun, dimana pada masa ini anak cenderung suka bermain dan mulai mengenal lingkungannya secara terintegrasi misalnya lingkungan sekolah, tempat tinggal, dan mulai mengenal permaiananyang begitu banyak model dan ragamnya.

Berdasarkan uraian diatas, diharapkan melalui penerapan model pembelajaran kooperatif tipe Student Teams Achievement Division (STAD) berbantuan media puzzle dapat mendorong motivasi siswa dalam menjalani siklus pembelajaran dan sekaligus dapat meningkatkan hasil belajar IPA siswa, sehingga komitmen pembelajaran itu dapat terealisasi dengan baik 


\section{Metode}

Jenis penelitian yang digunakan adalah Penelitian Tindakan Kelas (PTK). Adapun rencana yang akan dilaksanakan dalam penelitian tindakan kelas ini yaitu minimal terdiri dari 2 siklus, apabila pada siklus yang pertama permasalahan belum terselesaikan, maka akan dilanjutkan pada siklus yang berikutnya sampai target yang telah ditentukan tercapai dan tiap siklus terdiri dari satu pertemuan.

Langkah-langkah Penelitian

Adapun langkah-langkah dalam penelitian tindakan kelas ini adalah dengan menggunakan silklus terdiri dari perencanaan, pelaksanaan, pengamatan, dan refleksi.

\section{a. Perencanaan}

Membuat persiapan yang meliputi:

1. Membuat skenario pembelajaran

2. Menyusun rencana pelaksanaan pembelajaran (RPP)

3. Menyiapkan media atau alat bantu pembelajaran

4. Menyiapkan lembar kerja peserta didik

5. Menyiapkan lembar observasiaktivitas siswa dan guru

6. Membuat soal evaluasi

\section{b. Pelaksanaan}

Pada saat tahap ini adalah melaksanakan kegiatan belajar dikelas sesuai dengan Rencana Pelaksanaan Pembelajaran (RPP) yang telah dibuat.

\section{c. Observasi}

Pada tahap ini dilaksanakan observasi terhadap pelaksanaan tindakan yang dilakukan selama pembelajaran berlangsung dengan menggunkan lembar observasi yang telah dibuat. Observasi dapat mengukur tingkah laku individu ataupun proses terjadinya suatu kegiatan yang dapat diamati, baik dengan situas yang sebenarnya maupun dalam situasi yang buatan (Nana Sudjana, 2009 : 84), yang menjadi pusat observasi adalh segala aktivitas yang dilakukan oleh guru dan siswa dalam proses pembelajaran.

\section{d. Refleksi}

Refleksi yaitu kegiatan untuk mengemukan kembali apa yang sudah terjadi. Pada tahap ini peneliti bersama guru mengkaji kekurangan dan hambatan yang muncul untuk mendapatkan alternatif pemecahan masalah yang terbaik dari tindakan yang telah diberikan dengan memperhatikan hasil observasi dan evaluasi.

Pengumpulan data dalam penelitian ini adalah menggunakan metode tes. Berdasarkan metode tersebut, maka instrument yang digunakan dalam penelitian ini adalah lembar soal tes kemampuan menyelesaikan soal dalam bentuk pilihan ganda.

Dalam menganalisis data digunakan metode analisis statistik deskriptif kualitatif dan kuantitatif, yakni suatu cara pengolahan data yang dilakukan dengan jalan menyusun sistematis dalam bentuk angka-angka atau presentase mengenai suatu objek yang diteliti. 
Analisis data dilakukan dengan mengolah data yang terkumpul. Data ini dianalisis menggunakan analisis deskriptif kunatitatif adalah suatu cara mengolah data yang dilakukan dengan jalan menyusun secara sistematis dalam bentuk angka-angka dan/atau persentase mengenai suatu objek yang diteliti, sehingga diperoleh kesimpulan umum (Agung, 2010:8). Analisis deskriptif kuantitatif digunakan untuk mengkonversikan presentase hasil observasi secara keseluruhan kedalam penilaian acuan patokan (PAP) skala 5 yang menunjukan kategori kemampuan siswa dan mengkonversiskan indeks peningkatan rata-rata persentase hasil observasi kedalam kategori indeks peningkatan rata-rata persentase hasil observasi.

Setelah presentase rata-rata kemampuan menyelesaikan soal tes siswa SD N 4 Kaliuntu didapat, maka hasilnya dikonversikan ke dalam tabel PAP skala lima, seperti terlihat pada tabel berikut. Dalam menganalisis data digunakan metode analisis secara deskriptif, yaitu dengan menghitung rata-rata nilai aktifitas belajar siswa menggunakan rumus, Mean dan Rata-rata persentase.

\begin{tabular}{clcc}
\hline No & \multicolumn{1}{c}{ Rentangan Nilai } & Kategori & Keterangan \\
\hline 1 & $90-100$ & Sangat baik & Sangat tinggi \\
\hline 2 & $80-89$ & Baik & Tinggi \\
\hline 3 & $65-79$ & Cukup & Sedang \\
\hline 4 & $55-64$ & Kurang & Rendah \\
\hline 5 & $0-54$ & Sangat kurang & SangatRendah \\
\hline \multicolumn{2}{r}{} & \multicolumn{2}{c}{ Sumber: Koyan $(2011: 119)$}
\end{tabular}

1. Penelitian ini akan dianggap berhasil, jika nilai rata - rata kelas meningkat dengan perolehan persentase penguasaan diatas 80atau berada dalam kategori baik, berdasarkan konversi PAP skala lima yaitu 80-89(Sumber, Agung, 2016: 146)

2. Hasil belajar siswa tuntas dengan nilai $\geq 70$ sesuai KKM yang telah ditentukan,dan secara klasikal minimal $85 \%$ siswa tuntas serta nilai rata-rata kelas meningkat

3. Aktivitas belajar siswa tergolong baik aktif terhadap proses belajar mengajar yakni apabila minimal nilai akhir aktivitas siswa $\geq 25,00$ (tergolong aktif atau sangat aktif).

4. Kinerja guru tergolong baik atau memperoleh nilai akhir $\geq 50,00$

\section{Hasil dan Pembahasan}

Hasil tes siklus I dapat dilihat dalam tabel 6 berikut ini. Tabel 6. Distribusi Frekuensi Hasil Tes Siklus I

\begin{tabular}{|c|l|c|c|}
\hline No & Nilai & Frekuensi & Presentase \\
\hline 1 & 50 & 2 & $5,26 \%$ \\
\hline 2 & 55 & 2 & $5,26 \%$ \\
\hline 3 & 60 & 9 & $23,68 \%$ \\
\hline 4 & 65 & 4 & $10,52 \%$ \\
\hline 5 & 70 & 3 & $7,89 \%$ \\
\hline
\end{tabular}




\begin{tabular}{|c|l|c|c|}
\hline No & Nilai & Frekuensi & Presentase \\
\hline 6 & 75 & 2 & $5,26 \%$ \\
\hline 7 & 80 & 4 & $10,52 \%$ \\
\hline 8 & 85 & 6 & $15,78 \%$ \\
\hline 9 & 90 & 3 & $7,89 \%$ \\
\hline 10 & 95 & 2 & $5,26 \%$ \\
\hline 11 & 100 & 1 & $2,63 \%$ \\
\hline
\end{tabular}

Berdasarkan tabel 6, dapat dilihat siswa yang sudah mencapai KKM sebanyak 21 siswa $(55,26 \%)$ dan siswa yang belum mencapai KKM sebanyak 17 siswa $(44,73 \%)$. Nilai rata-rata kelas pada siklus I adalah 72,63 . Nilai tertinggi yang diperoleh siswa adalah 100 dan nilai terendah 50 .

Pencapaian nilai siswa dalam kegiatan siklus I dapat didistribusikan dalam kriteria seperti pada tabel 7 berikut ini.

Tabel 7. Kriteria Hasil Tes IPA Siklus I

\begin{tabular}{|c|c|c|c|}
\hline Skor & Kriteria & Jumlah & Presentase \\
\hline $85-100$ & $\begin{array}{c}\text { Sangat } \\
\text { baik }\end{array}$ & 12 & $31,57 \%$ \\
\hline $75-84$ & Baik & 6 & $15,78 \%$ \\
\hline $65-74$ & $\begin{array}{c}\text { Cukup } \\
\text { baik }\end{array}$ & 7 & $18,42 \%$ \\
\hline $51-64$ & Kurang & 11 & $28,94 \%$ \\
\hline$\leq 50$ & Gagal & 2 & $5,26 \%$ \\
\hline
\end{tabular}

Berdasarkan tabel 5 di atas, dapat dilihat bahwa nilai siswa berada pada kriteria gagal ( $\leq 50)$ adalah 2 siswa atau $5,26 \%$. Siswa yang mencapai kriteria kurang (51-64) sejumlah 11 siswa atau sekitar $28,94 \%$. Siswa yang mencapai kriteria cukup (65-74) sejumlah 7 siswa atau $18,42 \%$. Kriteria baik (75-84) berjumlah 6 siswa atau $15,78 \%$ dan baru ada siswa yang mencapai nilai dengan kriteria sangat baik (85-100) adalah 12 siswa atau $31,57 \%$.

Gambar 3. Grafik Kriteria Hasil Tes IPA Siklus I

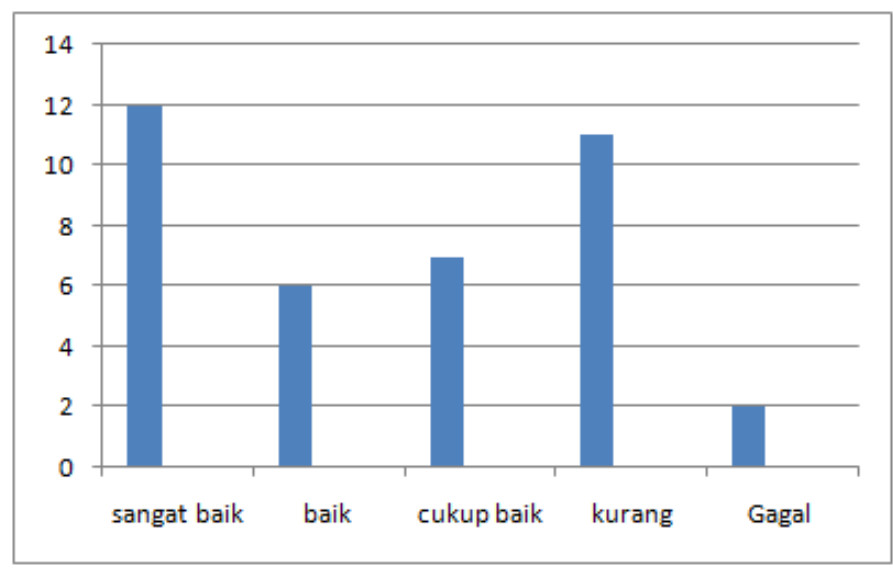


Dari data di atas dapat disimpulkan bahwa setelah dilakukan tindakan siklus I terjadi peningkatan hasil belajar siswa. Nilai rata-rata kelas yang pada saat pra tindakan sebesar 67,69, pada siklus I sudah meningkat menjadi 72,63. Persentase ketuntasan belajar siswa yang mencapai KKM juga mengalami peningkatan. Pada saat pratindakan, siswa yang mencapai KKM sebesar $55,26 \%$ sedangkan pada siklus I sudah mencapai $60,52 \%$.

Adapun hasil yang diperoleh dari pembelajaran siklus II dapat disajikan dalam tabel 8 berikut ini.

Tabel 8. Distribusi Frekuensi Hasil Tes Siklus II

\begin{tabular}{|c|c|c|c|}
\hline No & Nilai & Frekuensi & Presentase \\
\hline 1 & 50 & 0 & $0 \%$ \\
\hline 2 & 55 & 0 & $0 \%$ \\
\hline 3 & 60 & 2 & $5,26 \%$ \\
\hline 4 & 65 & 2 & $5,26 \%$ \\
\hline 5 & 70 & 2 & $5,26 \%$ \\
\hline 6 & 75 & 8 & $21,05 \%$ \\
\hline 7 & 80 & 8 & $21,05 \%$ \\
\hline 8 & 85 & 7 & $18,42 \%$ \\
\hline 9 & 90 & 5 & $13,15 \%$ \\
\hline 10 & 95 & 2 & $5,26 \%$ \\
\hline 11 & 100 & 2 & $5,26 \%$ \\
\hline
\end{tabular}

Berdasarkan tabel 8, dapat dilihat bahwa siswa yang sudah mencapai KKM $\geq 70$ sebesar $89,47 \%$ atau sebanyak 34 siswa. Sedangkan siswa yang belum mencapai KKM tinggal 4 siswa. Nilai terendah pada siklus II ini adalah 60, sementara nilai tertinggi sudah mencapai 100. Hasil belajar IPA siswa kelas V SD Negeri 4 Kaliuntu rata-rata masuk pada kriteria sangat baik (86-100) yaitu sebesar $23,68 \%$. Untuk lebih jelasnya dapat dilihat pada tabel berikut ini.

Tabel 9. Kriteria Hasil Tes IPA Siklus II

\begin{tabular}{|c|c|c|c|}
\hline Skor & Kriteria & Jumlah & Presentase \\
\hline $\begin{array}{c}85- \\
100\end{array}$ & $\begin{array}{c}\text { Sangat } \\
\text { baik }\end{array}$ & 9 & $23,68 \%$ \\
\hline $75-84$ & Baik & 23 & $60,52 \%$ \\
\hline $65-74$ & $\begin{array}{c}\text { Cukup } \\
\text { baik }\end{array}$ & 4 & $10,52 \%$ \\
\hline $51-64$ & Kurang & 2 & $5,26 \%$ \\
\hline$\leq 50$ & Gagal & 0 & $0 \%$ \\
\hline
\end{tabular}


Berdasarkan kriteria di atas, gambaran pencapaian hasil belajar siswa IPA ranah koginitif $V$ SD Negeri 4 Kaliuntu pada siklus II dapat disajikan pada gambar 4 berikut ini.

Gambar 4 Grafik Kriteria Hasil Tes IPA Siklus II

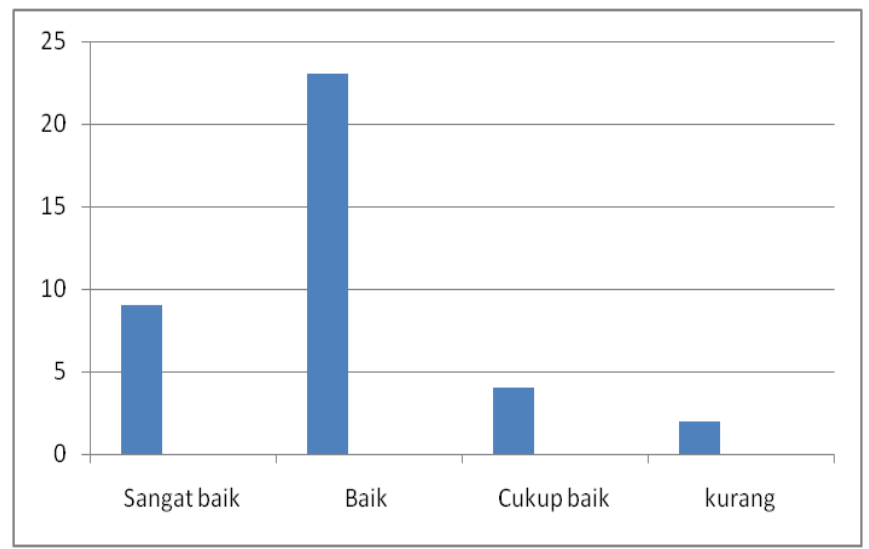

Berdasarkan data di atas dapat dilihat bahwa pada siklus II terjadi peningkatan pada nilai rata-rata kelas yang mencapai 80,65 . Dari data tersebut, rata-rata kelas dalam siklus II ini sudah mencapai kategori baik, berdasarkan pedoman konversi PAP skala lima yaitu 80-89. Sedangkan persentase ketuntasan secara klasikal minimal 85\%, juga sudah terpenuhi yaitu mencapai sebesar $89,47 \%$ atau sebanyak 34 siswa dari 38 siswa.

Peningkatan hasil tindakan pada siklus I dan siklus II dapat dilihat pada tabel $10 \mathrm{di}$ bawah ini.

Tabel 10. Perbandingan Hasil belajar IPA Pra Tindakan, Siklus I, dan Siklus II

\begin{tabular}{|l|c|c|c|}
\hline \multicolumn{1}{|c|}{$\begin{array}{c}\text { Aspek yang } \\
\text { diamati }\end{array}$} & $\begin{array}{c}\text { Pra } \\
\text { tindakan }\end{array}$ & Siklus I & $\begin{array}{c}\text { Siklus } \\
\text { II }\end{array}$ \\
\hline Nilai tertinggi & 80 & 100 & 100 \\
\hline Nilai terendah & 60 & 50 & 60 \\
\hline Nilai rata-rata & 67,69 & 72,63 & 80,65 \\
\hline $\begin{array}{l}\text { Jumlah siswa yang } \\
\text { belum mencapai } \\
\text { KKM }\end{array}$ & 16 & 17 & 4 \\
\hline $\begin{array}{l}\text { Jumlah siswa yang } \\
\text { telah mencapai } \\
\text { KKM }\end{array}$ & 12 & 11 & 34 \\
\hline $\begin{array}{l}\text { Persentase } \\
\text { ketuntasan klasikal }\end{array}$ & $55,26 \%$ & $60,52 \%$. & $89,47 \%$ \\
\hline
\end{tabular}

Berdasarkan tabel 11 dapat disimpulkan bahwa nilai rata-rata kelas setelah dilakukan tindakan mengalami peningkatan dari kondisi awal pra tindakan 67,69 menjadi 72,63 pada siklus I dan 80,65 pada siklus II. Persentase pencapaian KKM secara klasikal juga mengalami peningkatan dari kondisi awal pra tindakan 55,26\% menjadi $60,52 \%$ pada siklus I dan $89,47 \%$ pada siklus II. 


\section{Pembahasan}

Berdasarkan nilai rata-rata di setiap akhir siklus kegiatan pembelajaran yang menggunakan model pembelajaran Cooperative Learning tipeSTADmenunjukkan terjadi peningkatan hasil belajar ranah kognitif IPA siswa kelas V SD Negeri 4 Kaliuntu Kota Singaraja Kabupaten Buleleng. Peningkatan nilai rata-rata kelas sebesar 8,02 dari 72,63pada siklus I menjadi 80,65pada siklus II. Persentase jumlah siswa yang mencapai nilai KKM atau dinyatakan tuntas belajar secara klasikal juga terjadi peningkatan sebesar $28,95 \%$, dari $60,52 \%$ pada siklus I menjadi $89,47 \%$ pada siklus II. Pada siklus I terdapat 17 siswa yang belum mencapai KKM, sedangkan pada siklus II tinggal 4 siswa yang belum mencapai KKM. Dapat dikatakan bahwa pada siklus II ada kenaikan 13 siswa yang telah mencapai KKM.

Peningkatan hasil belajar IPA terjadi sangat signifikan pada siklus II karena peneliti telah menerapkan 5 komponen model pembelajaran Cooperative Learning tipe STAD dalam pembelajaran IPA secara tepat. Komponen utama model pembelajaran Cooperative Learning tipe STAD yaitu Presentasi kelas (Class Presentation), Kerja kelompok (Teams Works), Kuis (quizzes), Peningkatan Nilai Individu (Individual Improvement Score), Penghargaan Kelompok (Team Recognation).

\section{Simpulan dan Saran}

Berdasarkan hasil analisisi data yang telah disajikan, maka dapat disimpulkan sebagai berikut.

Dengan menerapkan model Cooperative Learning tipe STAD dapat meningkatkan hasil belajar IPA siswa kelas V di SDN 4 Kaliuntu. Hal ini terlihat dari adanya peningkatan hasil belajar pada siklus I ke siklus II, yaitu pada siklus I, nilai rata-rata kelas adalah 72,63 yang berada pada kategori cukup baik, dengan persentase ketuntasan belajar $60,52 \%$, sedangkan pada siklus II, nilai rata-rata kelas adalah 80,65 yang berada pada kategori baik, dengan persentase ketuntasan belajar 89,47\%. Perubahan ini terjadi karena penerapan model Cooperative Learning tipe STAD dilaksanakan secara seksama dengan memperhatikan karakteristik dan kesulitan siswa.

Saran yang dapat disampaikan berdasarkan penelitian yang telah dilakukan adalah sebagai berikut.

1. Siswa hendaknya dapat mengikuti proses pembelajaran dengan baik dan aktif sehingga tujuan pembelajaran dapat tercapai.

2. Guru hendaknya lebih berinovasi dalam pembelajaran dengan cara memilih dan menggunakan model pembelajaran inovatif untuk menciptakan suasana belajar yang kondusif, sehingga dapat meningkatkan keterampilan berpikir kritis siswa.

3. Model Cooperative Learning tipe STAD berbantuan media puzzle dapat dijadikan masukan dan acuan bagi kepala sekolah untuk mengambil kebijakan dalam upaya meningkatkan kualitas pembelajaran, terutama pembelajaran IPA. 
4. Penelitian ini dapat dijadikan bahan bandingan bagi peneliti lain yang berminat untuk mengadakan penelitian lebih lanjut mengenai model Cooperative Learning tipe STAD berbantuan media puzzle dengan memperhatikan kendala-kendala yang dialami sebagai bahan pertimbangan untuk menyempurnakan pelaksanaan penelitian selanjutnya.

\section{Daftar Rujukan}

Arikunto .S. dkk. 2010. Penelitian Tindakan Kelas, Jakarta: Bumi Aksara

Daryanto. 2011. Media Pembelajaran. Bandung : PT Sarana Turorial Nurani Sejahtera

Hamalik, Oemar. 2010. Proses Belajar Mengajar. Jakarta : Bumi Aksara

Rusman. 2012. Model-Model Pembelajaran. Jakarta: PT RajaGrafindo Persada

Slavin. 2008. Pembelajaran Kooperatif. Yogyakarta: Pustaka Pelajar.

Nukencana, W dan Sunartana. 1990. Evaluasi Hasil Belajar. Surabaya: Usaha Nasional

Sudjana, Nana. 1997. Penilaian Hasil dan Proses BelajarMengajar. Bandung: Remaja Rosdakarya

http://denokdwiapriliana.blogspot.com/2011/05/hakikat-konsep-dasar-IPA-di-sd.html, 7 februari 2018

http://zhensafandi.wordpress.com/2012/09/25/konsep-konsep-dasar-mediapembelajaran, 7 februari 2018 